\begin{tabular}{c} 
Volume and Issues Obtainable at Center for Sustainability Research and Consultancy \\
Journal of Business and Social Review in Emerging Economies \\
ISSN: 2519-089X (E): 2519-0326 \\
Volume 6: Issue 2 June 2020 \\
ᄃSRட \\
Journal homepage: $\underline{\text { www.publishing.globalcsrc.org/jbsee }}$ \\
\hline
\end{tabular}

\title{
Effects of Process-Genre Approach on Writing Anxiety among English Academic Writing Learners in Pakistan
}

\section{${ }^{1}$ Abrar Ajmal, ${ }^{2}$ Humaira Irfan}

${ }^{1}$ Ph.D. Scholar, Division of Education, University of Education, Lahore Pakistan, abrarajmal@ fccollege.edu.pk

${ }^{2}$ Assistant Professor, Department of English, University of Education, Township Campus, Lahore Pakistan, humaira.irfan@ue.edu.pk

\section{ARTICLE DETAILS}

\section{History}

Revised format: May 2020

Available Online: June 2020

\section{Keywords}

Academic Writing, Teaching

Writing Approaches, Process-

genre Approach, Second

Language writing Anxiety, ESL

Writing Pedagogy

JEL Classification

A20, P36, P46, Z13

\begin{abstract}
Writing ability is a prerequisite to be successful in academic pursuits. Pakistani student writers experience a range of issues, including psychological, cognitive, social, and linguistic when they write. Writing instructors need to use appropriate teaching strategies and methodologies to tackle writing-related issues (Khan \& Zaki, 2018). Most of the Pakistani ESL writing students are educated through the stereotypical teacher-centered Product Approach focuses on the memorization of ready-made answers. As a result, the learners face great challenges; ESL writing Anxiety is one of the major challenges (Gopang, Bughio, \& Pathan, 2018). The aim of this quasiexperimental study based on predominantly the post-positivist and the marginally pragmatic philosophical framework is to explore the effects of the Process-Genre Approach (PGA) on writing anxiety among ESL intermediate/pre-university students in Pakistan. The research tools were included to collect data: Second Language Writing Anxiety Inventory (SLWAI), 22-item multidimensional questionnaire, and interviews to investigate the effects of the experiment on writing apprehensions. Data were collected before and after the designed academic writing module based on the Process-Genre approach and pair sample t-test was applied to yield statistically significant results showing that average writing anxiety score was reduced from 77.17 to 66.72 among control group and from 73.57 to 50.25 among the experimental group. Quantities data collected through interviews were analyzed using thematic analysis also supplement that the treatment was effective to reduce writing anxiety.
\end{abstract}

\section{OPEN ACCESS}

(C) 2020 The authors, under a Creative Commons Attribution-

NonCommercial 4.0

Corresponding author's email address: abrarajmal@fccollege.edu.pk

Recommended citation: Ajmal, A. and Irfan, H. (2020). Effects of Process-Genre Approach on Writing Anxiety among English Academic Writing Learners in Pakistan. Journal of Business and Social Review in Emerging Economies, 6(2), 741-752

\section{Introduction}

Importance of English Language is obvious because it is the language of communication across the world and the need for L2 writing scholarship considered much important due to the impact of English as a lingua Franca (Nguyen, 2019). English as an official language is being used and taught in most of the educational institutions in Pakistan at 
different levels (Coleman \& Capstick, 2012). Academic Writing is an important part of learning and it should be given more attention to preparing learners to cope with both communicative and academic needs. As Davidson (2018) puts, "Writing is important because it is used widely in education and on the job. If students do not know how to express themselves, they will not be able to communicate well with peers, employers, professors, or just about anyone". English language has an official position in Pakistan and is being used for multiple functions (Khan, 2012). In real-life situations, writing in English is one of the essential language skills required in Pakistan for correspondence, messages, notices, reports, and so on or scholastic undertakings such as homework, research paper, and assessments. Consequently, it is required for Pakistani English learners to get better control over English language writing skills.

Writing is a talent that is required through one's life in several contexts. Besides, academic writing has its own set of practices and regulations. Academic writing pursues an exacting tenor and sticks to the rules and principles of grammar, punctuation, and spelling (Fareed, Ashraf \& Bilal, 2016). Content of a successful English as a second language writer must be consistent, organized, intriguing, and justifiably organized with an extensive range of Lexis and dominance of traditions in mechanics (Mastsuda \& Tardy, 2007). Writing is particularly a taxing process that requires the student to have control over different components and competencies (Dar \& Khan, 2015).

Pedagogical research in the field of writing has experienced many major shifts over the last four decades, e.g. Product, Process, Genre, and the combined Process-Genre Approach (Abate, 2019). The majority of the intermediate/preuniversity ESL writing students are educated through a Product Approach that is teacher-centered and conservative in nature focusing on the memorization of ready-made answers. Because of this approach, beginners face immense challenges, including writing anxiety (Siddique \& Singh, 2016).

\section{Problem Statement}

Writing is one of the most difficult areas of learning a second language. It depends on the suitable usage of language with structural exactness and communicative abilities (Mahboob, 2014). Hence, figuring out how to write has increased significantly during the previous two decades because of two factors: its utilization as an instrument for successful correspondence of thoughts, and the broad research work completed around there to look at different issues faced by L2 writers (Dar \& Khan, 2015). It is argued that poorly written work aptitudes begin from two factors: the instructor and the student. Instructors need to use proper teaching methods to deal with the issues of student writers, including giving brief and viable input to understudies, and most crucially, teachers' lack of ability to employ appropriate teaching strategies and methodologies (Rizwan, Akhtar \& Sohail, 2017).

Sajid and Siddiqui (2015) think that English language courses based on general English with traditional writing pedagogy cannot equip the requirements of university students. "Thus, a critical pragmatic approach to develop academic English language can enhance writing competence of novice writers for academic discourse and critical thinking about the conventions". According to Fareed and Khan (2015) "English language community in Pakistan regularly shares composing related issues". One of the key issues under discussion is writing anxiety or writing apprehensions, the majority of the instructors do not utilize the word anxiety; they may utilize confusion, strain, and hesitance to composing. The dominant part of EFL/ESL writing students faces a high level of writing anxiety (Latif, 2007).

The communicative approach has been introduced for ESL students in universities for the last few years. The difficulty for a significant number of students initiates as they enter university since they do not have the required abilities and skills to deal with the writing courses. Great importance is given to writing skills at universities, keeping in view the real-life leanings; therefore, effectual teaching writing approaches need to be focused on to help those learners who cannot put together an appropriate piece of academic writing, without considerable writing apprehension. Many of the students sign up for ESL writing courses with different levels of language proficiency and different learning styles in Pakistan. English as a second language (ESL) students in Pakistan need to meet the standards for admission and continuation of their university studies, particularly in writing English Language (Atique $\&$ Khan, 2015). As a matter of fact, in Pakistan school and college curricula have a past of outdated language teaching methods like many other ESL contexts, where students are taught their second language chiefly by memorizing grammatical formations and secluded expressions. This prevalent teacher-centered setting dispirits thought process 
and originality. It is required to introduce effective approaches to writing instruction for their better writing performance before entering a course at the university level. Teaching academic writing to ESL learners at the intermediate level can be a complicated task because some teachers and a large number of students are not entirely committed to the Process and Genre, comparable new approaches in the context. These above-discussed conditions are not much different from other ESL/EFL contexts, the role and place of English Language especially in academic settings (Getnet, 2019). Fareed, Jawed, and Awan (2018) find out in the study at the pre-university level that there are issues with the practices of teaching writing skills. The study also supplements that there are some more problems while teaching writing skills, such as deficiency of pre-writing activities, learners' lacking command over "vocabulary, grammar, spellings, and punctuation". It is thought that the Product approach should gradually be replaced by the relatively new concept a combined Process-Genre approach which would prove more conducive and helpful to ESL students. It is considered that it should be investigated to propose some viable ideas, plans, approaches, and/or practices in reducing writing anxiety among ESL students.

\section{Literature Review}

Anxiety is defined as "a subjective feeling of tension, apprehension, nervousness, and worry associated with an arousal of the autonomic nervous system" (Horwitz, 2010). And he is the first who argues that language anxiety or writing apprehension is 'situation-specific anxiety' which is triggered by a specific situation, for example speaking to an audience. In his opinion "Foreign Language Anxiety (FLA) or Second Language Anxiety (SLA)" is a compound and 'multidimensional phenomenon'. Negative anxious feelings that cause some blockage in the writing process are termed as writing anxiety, defined by Topuzkanamis (2015), "the worry a person feels towards a task of qualified writing". According to Huwari, \& Al-Shboul, (2016) Daly and Miller (1975) best define writing anxiety as "a subjective, complex of attitudes, emotional and behavior interaction which reinforce each other".

Writing involves mainly cognitive and linguistic processes that require higher-order thinking to put thoughts on paper. Language knowledge, including vocabulary, spelling, syntax, and grammar is a prerequisite for writing. Missing any of the components of language knowledge could be a reason for writing anxiety. Likewise, the cognitive process is mainly required for writing and if both processes have some deficiencies, it triggers feelings of unpleasantness, uneasiness, and discomfort which are labeled as writing anxiety (Jennifer \& Ponniah 2017). Behavior and Attitude of second language writers also need to be studied when we are looking into their learning environment regarding writing anxiety.

Cheng (2017) subdivides the construct of writing anxiety into three subdivisions: "cognitive, somatic and avoidance behavior". Somatic anxiety is about the physiological (physical) aspects including heart-pounding, perspiration, trembling, fear, strain, and uneasiness. 'Cognitive anxiety' is the negative feeling about the entire writing thought process, fear of negative washback, and related negative concerns. The third subdivision is the result of earlier discussed types: behavior and attitude of averting the writing situations or writing activities are termed as 'avoidance behavior.'

There are several different methods to teach ESL writing college students. But, in line with Raims (1983) "there isn't one reply to this inquiry of how exactly to instruct writing in ESL lessons". ESL writing pedagogy has changed its focus on different times, chiefly because of L1 creating pedagogy as well as also the consequences of different research workers from the field (Ferris \& Hedgock, 2005). The various methods of writing instruction for ESL students are mostly split into three important branches: text-oriented, writer-oriented along with reader-oriented (Abate, 2019; Myhill \& Locke, 2007). In this approach, the cognitive aspect expresses that writing is a nonlinear collaborative process of planning, writing, and previewing (Nguyen, 2019). However, there are limitations in ignoring the social dimension of writing (Paltridge, 2014). The next reader-oriented approach is presented from a socio-cultural angle. The center of attention revolves around this approach around the purpose of writing, audience, and context. Zammit and Tan (2016) highlighted different stages involved in the genre approach are: "negotiation of the field, deconstruction, joint construction, and independent construction". This approach was critiqued for barring the learners' creativity, but this point was answered by Hedgecock (2012) that ESL learners would be deprived if not exposed to different genres because they are often unacquainted with L2 writing conventions. Procedures according to the genre instructions, focus on the limitations of content and form that must follow. 
Different above discussed approaches certainly have limitations and the concept of a combination is something novel in the area of ESL writing pedagogy. Badger and white (2000) introduced the process-genre joint strategy; it is essentially a blend of models, both: process-based strategy and the genre-based approach and it seems suitable to compose texts in a comfortable genre (Kim \& Kim, 2005). This dual approach involves teaching the appropriateness of language along with different revision steps through the process to produce the final draft. In this combined approach writing is viewed both from the perspective of reader and writer. One of the features of this approach is a strong linkage between different stakeholders, including writer, reader, teacher/instructor both in and outside class. Another distinction of this approach is that it integrates all communication skills: listening, reading, writing, and speaking (Abate, 2019). This method permits students to examine the association between "purpose and form as they make use of the procedures of prewriting, drafting, revision, and editing". Utilizing these steps develops students' understanding of the procedure and also different text types. The process genre procedure is separated into these six steps: "(1) preparation, (2) modeling and bolstering, (3) Planning, (4) joint constructing, (5) independent construction, and (6) revising" (Badger \& White, 2000).

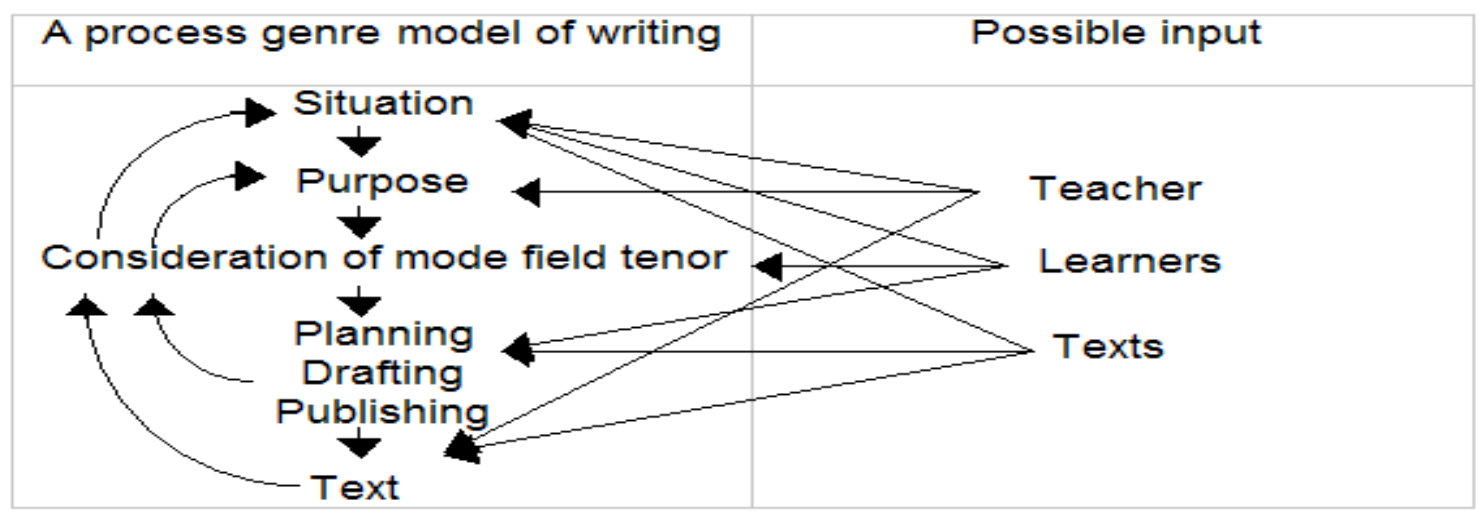

Figure 1.A process genre model of writing (Badger \& White, 2000)

\section{Research Questions}

RQ1: What are the effects of the process-genre approach on writing anxiety in ESL writing students?

RQ2: What are the effects of the process-genre approach on "cognitive anxiety, somatic anxiety, and avoidance behavioral" aspect of ESL writing students?

\section{Methodology}

This research is following the quasi-experimental design. One of the aims is to study the effect of a certain variable on other variables, "the experimental method is the method that directly concerns itself with the question of causality" (Smith, 1991: 177). According to the principles recognized by Cohen, Manion, and Morrison, (2002), the quasiexperimental design of this study as follows:

$\begin{array}{lccc}\text { "Experimental } & \mathrm{O} 1 & \mathrm{X} 1 & \mathrm{O} 2 \\ \text { Control } & \mathrm{O} 3 & \mathrm{X} 2 & \mathrm{O} 4 "\end{array}$

$\mathrm{O}=$ observation (1, 3 is the pre-test, and 2, 4 is the post-test),

$\mathrm{X} 1=$ the independent variable (treatment teaching writing with the process-genre approach)

$\mathrm{X} 2=$ teaching writing with the traditional Product approach

The total population of the samples was selected includes 1500 intermediate/ pre-university students of the FCC school registered for the 2018-20 academic years. The students were gathered into 38 sections. From this, section E4 and E5 were selected as a sample of the study from the population of total intermediate/pre-university (12th grade) students. Consequently, section E4 students $(n=40)$ were under experimental group (EG) and section E5 students $(\mathrm{n}=40)$ were under the controlled group $(\mathrm{CG})$. The convenience sampling strategy is being followed, which involves choosing the easily accessible individuals to serve as respondents (Cohen, Manion \& Morrison, 2002). In this study, the participants are ESL intermediate students from my parent institution Forman Christian College (A Chartered University), Lahore, Pakistan. The quasi-experimental study was carried out involving intermediate/ pre-university (12th grade) students in their normal classes over a period of one (12 weeks) term. Eighty (80) participants have the 
same academic abilities and from similar backgrounds were divided into two groups. The students of these sections or groups were taken as subjects in this study due to their maximum uniformity both in terms of previous academic achievements i.e. marks in Secondary Scholl certificate (SSC) exam and socioeconomic backgrounds. One of the lists was selected randomly to be the control group and others to be experimental. The ethical obligations had been met by letting the subjects know that the collected data would be used to study the construct of ESL writing anxiety and keeping the purpose of providing findings, suggestions, and recommendations for the improvement of the writing skills of the students of Pakistan. It was confirmed and ensured to the subjects for their complete anonymity

The Second Language Writing Anxiety Inventory (SWLAI), which is a multidimensional Licket Scale 22- item questionnaire developed by Cheng (2004) is adopted for the study after the due process regarding permission seeking from the tool developer. The study is intended to see sub-levels of writing anxiety: "Somatic Anxiety, Avoidance Behavior, and Cognitive Anxiety" (Cheng, 2004). The results are compared to see if there are any significant effects of the treatment on the students' writing anxiety. The SLWAI questionnaire was administered before and after the intervention to collect data.

The experimental group was explicitly taught by using the process-genre based approach to improve their writing and shrink writing anxiety/apprehensions. Twelve sessions were devoted to teaching the key concepts and skills. Two maximum similarly qualified and experienced teachers were requested to take part in the study and teach 12 weeks writing course to the treatment group by using the process - genre approach. Lessons were planned with the help of the involved teachers according to the aims and objectives and the certain guidelines and principles of the course design (Yalden, 1987). The course was designed and divided into different units based on the prescribed syllabi from the government of the Punjab Textbook Board and Punjab curriculum wing. The designed lessons shared with the seniors and after validation and modifications from the experts were applied after the permissions from the concerned authorities to experiment.

Interviews were conducted from a randomly selected control group and experimental group participants at the beginning of the research experiment. Later, after the intervention again questions were asked from the 15 randomlyselected experimental groups (EG) participants from (High-anxiety, Moderate-anxiety, and Low-anxiety bands) during the focus group discussion to explore the perception/opinion and experiences regarding the effectiveness of the process genre approach for writing anxiety.

The framed interview questions based on subdivisions of writing anxiety was listed in table 1 . Responses were codified and analyzed by thematic analysis. The results of the interviews were viewed to identify major themes. The themes are very much alike to the results yielded through the questionnaire (SLWAI).

\section{Table1.}

\section{Interview Questions}

- What do you think while writing in English feel any nervousness at all?

- Do you feel heart pounding/perspiration / trembling/panic /freeze up or physical effect while writing under time constraint?

- Do you feel worried while writing English composition if they know that will be evaluated? And they feel worried about getting a poor grade?

- Are you often willing to writing your thoughts in English?

- Do you try your best to avoid the situation when you are asked to write English compositions?

- Do you complain of being blank and jumbled thoughts when you are asked to write in English?

- Are you worried about their language writing ability as compared to peers of that group? Or not worried about what other people think about your writing ability?

- Do you only write in English when you have no other option left?

- Do you have a fear of being derided/ridicule if another group member reads your writing?

- Do you try your best to make excuses if you are asked to write in English?

- Do you feel afraid if your sample writing is going to be discussed in the class? 


\section{Data Analysis and Findings}

The Likert-scale questionnaire (SLWAI) developed by Cheng (2014) is valued as: "1 (strongly disagree), 2 (disagree), 3 (neither agree nor disagree), 4 (agree), and 5 (strongly agree)". There are three identified subcategories by the developer as follows: "1- Cognitive Anxiety $(1,3,7,9,14,17,20,21), 2$ - Somatic Anxiety $(2,6,8,11,13,15,19)$, and 3Avoidance Behavior $(4,5,10,12,16,18,22)$ ". In this questionnaire, there are five questions $(1,4,17,18$, and 22$)$ due to the negative wording need to be administered by using the reverse scoring. The possible score ranging from a minimum of 22 to a maximum of 110 can be yielded from the participants' responses. According to Jennifer \& Ponniah (2017), the scores are divided into three bands: Low Anxiety score 50 and below, High Anxiety score 65 and above and Moderate Anxiety score ranging 50 to 65. Both groups: Control (CG) and experimental (EG) group students' scores in the pre and post-tests were collected and analyzed by using descriptive and inferential statistics. Paired samples t-test was used to equate the yielded mean anxiety scores of the two groups at the pre and posttest treatment stages. SPSS version 25 was used to calculate the pair sampled t-tests and descriptive statistics. The data which were collected through interviews was analyzed based on the qualitative technique of thematic analysis.

One of the most important issues is about the reliability of the questionnaire (Bonett \& Wright, 2015), following table

2 and table 3 show the Cronbach's Alpha values .832 and .818 respectively which shows good reliability of the SLWAI; Likert scale questionnaire.

Table 2

\section{Pre-Test Reliability Statistics}

Cronbach's

Alpha Based

on

Cronbach's Standardized

\begin{tabular}{lll} 
Alpha & Items & $\mathrm{N}$ of Items \\
\hline .832 & .831 & 22 \\
\hline
\end{tabular}

Table 3

Posttest Reliability Statistics

Cronbach's

Alpha Based

on

Cronbach's Standardized

\begin{tabular}{lll} 
Alpha & Items & N of Items \\
\hline .818 & .818 & 22 \\
\hline
\end{tabular}

Both groups were given the questionnaire to obtain the responses regarding ESL writing anxiety before the start of the intervention. The following table 4shows the descriptive statistics of all the 22 items on the questionnaire. The responses on the scale were analyzed and maintained that the majority of ESL students at the stage were experiencing a high level of the writing anxiety mean score was 75.41. The interviews of the selected students were also consistent with the findings that they experienced high anxiety while writing.

\section{Table 4}

\section{Pre-Test Descriptive Statistics}

\begin{tabular}{|c|c|c|c|c|c|c|}
\hline & $\mathrm{N}$ & Minimum & Maximum & Sum & Mean & $\begin{array}{l}\text { Std. } \\
\text { Deviation }\end{array}$ \\
\hline 1- Nervousness Denied & 80 & 1.00 & 5.00 & 197.00 & 2.4625 & 1.37743 \\
\hline $\begin{array}{l}\text { 2- Heart Pounding under } \\
\text { Time Constraint }\end{array}$ & 80 & 2.00 & 5.00 & 292.00 & 3.6500 & .99492 \\
\hline 3- Worried about Evaluation & 80 & 1.00 & 5.00 & 306.00 & 3.8250 & 1.12255 \\
\hline $\begin{array}{l}\text { 4- No Worries regarding free } \\
\text { Expression of Thoughts }\end{array}$ & 80 & 1.00 & 5.00 & 176.00 & 2.2000 & 1.22629 \\
\hline 5- Avoid to write in English & 80 & 1.00 & 5.00 & 305.00 & 3.8125 & 1.17024 \\
\hline $\begin{array}{l}\text { 6- Mind goes blank before } \\
\text { writing }\end{array}$ & 80 & 1.00 & 5.00 & 306.00 & 3.8250 & 1.23016 \\
\hline 7- Fear of comparison & 80 & 1.00 & 5.00 & 281.00 & 3.5125 & 1.25278 \\
\hline $\begin{array}{l}\text { 8- Physical Effects while } \\
\text { Writing }\end{array}$ & 80 & 1.00 & 5.00 & 316.00 & 3.9500 & 1.11264 \\
\hline $\begin{array}{l}\text { 9- Have Fear of Poor } \\
\text { Evaluation }\end{array}$ & 80 & 1.00 & 5.00 & 300.00 & 3.7500 & 1.27785 \\
\hline 10- Do Best Efforts to Avoid & 80 & 1.00 & 5.00 & 304.00 & 3.8000 & 1.20547 \\
\hline
\end{tabular}




\begin{tabular}{|c|c|c|c|c|c|c|}
\hline $\begin{array}{l}\text { 11- Thoughts jumbled under } \\
\text { Time Constraint }\end{array}$ & 80 & 1.00 & 5.00 & 316.00 & 3.9500 & 1.24168 \\
\hline $\begin{array}{l}\text { 12- Write in English if } \\
\text { Mandatory }\end{array}$ & & 1.00 & 5.00 & 304.00 & 3.8000 & 1.29654 \\
\hline $\begin{array}{l}\text { 13- Got panicky if asked to } \\
\text { write under Time Constraint }\end{array}$ & 80 & 1.00 & 5.00 & 292.00 & 3.6500 & 1.15944 \\
\hline $\begin{array}{l}\text { 14- Fear of being derided by } \\
\text { peers }\end{array}$ & 80 & 1.00 & 5.00 & 295.00 & 3.6875 & 1.08609 \\
\hline $\begin{array}{l}\text { 15- Freeze up if } \\
\text { Unexpectedly ask to write }\end{array}$ & 80 & 1.00 & 5.00 & 308.00 & 3.8500 & 1.30335 \\
\hline $\begin{array}{l}\text { 16- All possible Excuses to } \\
\text { avoid writing }\end{array}$ & 80 & 1.00 & 5.00 & 307.00 & 3.8375 & 1.17402 \\
\hline $\begin{array}{l}\text { 17- No worries about others } \\
\text { regarding my writing }\end{array}$ & 80 & 1.00 & 5.00 & 169.00 & 2.1125 & 1.11371 \\
\hline $\begin{array}{l}\text { 18- Seek chances and } \\
\text { possibilities to write }\end{array}$ & 80 & 1.00 & 5.00 & 182.00 & 2.2750 & 1.16895 \\
\hline $\begin{array}{l}\text { 19- Whole body feels rigid } \\
\text { and tense while writing }\end{array}$ & 80 & 1.00 & 5.00 & 310.00 & 3.8750 & 1.20521 \\
\hline $\begin{array}{l}\text { 20- Fear of being sampled in } \\
\text { class }\end{array}$ & 80 & 1.00 & 5.00 & 298.00 & 3.7250 & 1.24245 \\
\hline $\begin{array}{l}\text { 21- Fear of being Poorly } \\
\text { Rated }\end{array}$ & 80 & 1.00 & 5.00 & 289.00 & 3.6125 & 1.08492 \\
\hline $\begin{array}{l}\text { 22- Not worried and write in } \\
\text { English whenever possible }\end{array}$ & 80 & 1.00 & 5.00 & 180.00 & 2.2500 & 1.24778 \\
\hline Valid N (listwise) & 80 & & & & & \\
\hline
\end{tabular}

The following table 5 is about the responses of all participants after the duration of 12 weeks. The experimental group was taught ESL academic writing following the process-genre approach while the control group was taught the same content with the conventional product approach. The results show that there is a significant difference between both the groups; the CG mean score has been dropped to 66.72 from 77.17 and EG score has been dropped to 50.25 from 73.57. According to the bands referred by Jennifer \& Ponniah (2017) regarding ESL writing anxiety, in CG, although the score dropped, but still in the band of high levels of anxiety whereas, in EG the average score was dropped within the value of the low anxiety band.

\section{Table 5}

\section{Posttest Descriptive Statistics}

\begin{tabular}{|c|c|c|c|c|c|c|}
\hline & $\mathrm{N}$ & Minimum & Maximum & Sum & Mean & $\begin{array}{l}\text { Std. } \\
\text { Deviation }\end{array}$ \\
\hline 1- Nervousness Denied & 80 & 1.00 & 5.00 & 191.00 & 2.3875 & 1.32640 \\
\hline $\begin{array}{l}\text { 2- Heart Pounding under } \\
\text { Time Constraint }\end{array}$ & 80 & 2.00 & 5.00 & 224.00 & 2.8000 & 1.04821 \\
\hline 3- Worried about Evaluation & 80 & 1.00 & 5.00 & 225.00 & 2.8125 & 1.27382 \\
\hline $\begin{array}{l}\text { 4- No Worries regarding } \\
\text { free Expression of Thoughts }\end{array}$ & 80 & 1.00 & 5.00 & 167.00 & 2.0875 & 1.14950 \\
\hline 5- Avoid to write in English & 80 & 1.00 & 5.00 & 212.00 & 2.6500 & 1.20232 \\
\hline $\begin{array}{l}\text { 6- Mind goes blank before } \\
\text { writing }\end{array}$ & 80 & 1.00 & 5.00 & 230.00 & 2.8750 & 1.35362 \\
\hline 7- Fear of comparison & 80 & 1.00 & 5.00 & 217.00 & 2.7125 & 1.30427 \\
\hline $\begin{array}{l}\text { 8- Physical Effects while } \\
\text { Writing }\end{array}$ & 80 & 1.00 & 5.00 & 234.00 & 2.9250 & 1.33857 \\
\hline $\begin{array}{l}\text { 9- Have A Fear of Poor } \\
\text { Evaluation }\end{array}$ & 80 & 1.00 & 5.00 & 205.00 & 2.5625 & 1.32018 \\
\hline $\begin{array}{l}\text { 10- Do Best Efforts to } \\
\text { Avoid Writing Situations }\end{array}$ & 80 & 1.00 & 5.00 & 222.00 & 2.7750 & 1.34987 \\
\hline $\begin{array}{l}\text { 11- Thoughts jumbled under } \\
\text { Time Constraint }\end{array}$ & 80 & 1.00 & 5.00 & 219.00 & 2.7375 & 1.36636 \\
\hline $\begin{array}{l}\text { 12- Write in English if } \\
\text { Mandatory }\end{array}$ & 80 & 1.00 & 5.00 & 223.00 & 2.7875 & 1.42929 \\
\hline $\begin{array}{l}\text { 13- Got panicky if asked to } \\
\text { write under Time Constraint }\end{array}$ & 80 & 1.00 & 5.00 & 205.00 & 2.5625 & 1.16753 \\
\hline 14- Fear of being derided by & 80 & 1.00 & 5.00 & 210.00 & 2.6250 & 1.27662 \\
\hline
\end{tabular}


peers

15- Freeze up if 80

Unexpectedly ask to write

16- All possible Excuses to 80 avoid writing

17- No worries about others 80 regarding my writing

18- Seek chances and 80

possibilities to write

19- Whole body feels rigid 80

and tense while writing

20- Fear of being sampled in 80

class

21- Fear of being Poorly 80

Rated

22- Not worried and write in 80

1.00

5.00

227.00

2.8375

1.40923

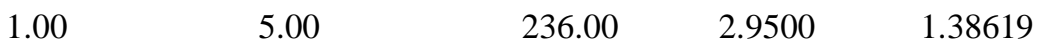

$1.00 \quad 5.00$

164.00

2.0500

1.02993

$1.00 \quad 5.00$

172.00

2.1500

1.08032

$1.00 \quad 5.00$

249.00

3.1125

1.35939

1.00

5.00

242.00

3.0250

1.36850

1.00

5.00

237.00

2.9625

1.30669

1.00

5.00

2.1000

1.12058

English whenever possible

Valid N (listwise)

80

One of the main reasons for selecting this inventory is that it consists of three subscales of writing anxiety termed as cognitive (as thinking of negative expectations, preconceived notions of writing performances), Somatic anxiety (as related to negative feelings like tension, fear, and physical effects) and Avoidance behavior (as the tendencies to avoid writing situations). This instrument is proved highly reliable and validly concluded through the processes of correlation and factor analysis (Cheng, 2004). The differences caused by the intervention in all three subscales in the experimental group were calculated. The average mean score of the Cognitive anxiety was dropped by $14 \%$, somatic anxiety score was dropped by $20 \%$ and avoidance behavior score was dropped by $18 \%$ respectively. This result shows the significant differences in all these three subscales of writing anxiety as the effects of the treatment.

In the study paired sample t-test was applied to answer the research question; that is a difference of scores caused by the newly introduced independent variable of process- genre teaching writing approach. The results of the paired sample t-test are shown in the following table 6 and 7 regarding the control group and table 8 and 9 regarding the experimental group.

\section{Table 6}

\section{Control Group Paired Samples Statistics}

\begin{tabular}{llllll}
\hline & Mean & $\mathrm{N}$ & Std. Deviation & Std. Error Mean \\
\hline Pair 1 & Pre Test Anxiety Score & 77.1750 & 40 & 13.27208 & 2.09850 \\
& Post Test Anxiety Score & 66.7250 & 40 & 11.46005 & 1.81199 \\
\hline
\end{tabular}

In table $6 \mathrm{t}$ values 8.720 is calculated by using the comparison of the mean score of pre and posttest anxiety scores of a control group which is 10.4500 . The test P-value is less than .05 which is considered as highly statistically significant results.

\section{Table 7}

\section{Control group Paired Samples Test}

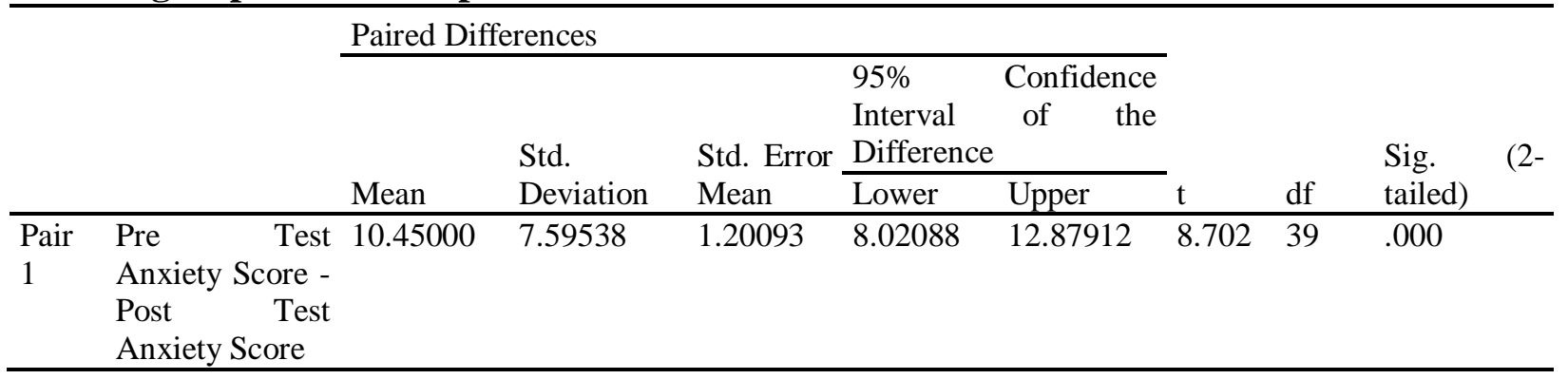




\section{Table 8}

\section{Experimental Group Paired Samples Statistics}

\begin{tabular}{llllll}
\hline & & Mean & N & Std. Deviation & Std. Error Mean \\
\hline Pair 1 & Pre Test Anxiety Score & 73.5750 & 40 & 11.40825 & 1.80380 \\
& Post Test Anxiety Score & 50.2500 & 40 & & 1.23452 \\
\hline
\end{tabular}

Table8 and 9 show the results of paired sample t-test values about the experimental group. The mean difference in the experimental group is 23.325 which is significantly greater than that of the control group and the $t$ value is 12.52 again greater as compared to the control group. The P-value is also less than 0.05 shows the highly statically significant difference. These numbers help to answer the research question that is a significant reduction in the writing anxiety scores among experimental group participants as compared to the control group.

\section{Table 9}

\section{Experimental Group Paired Samples Test}

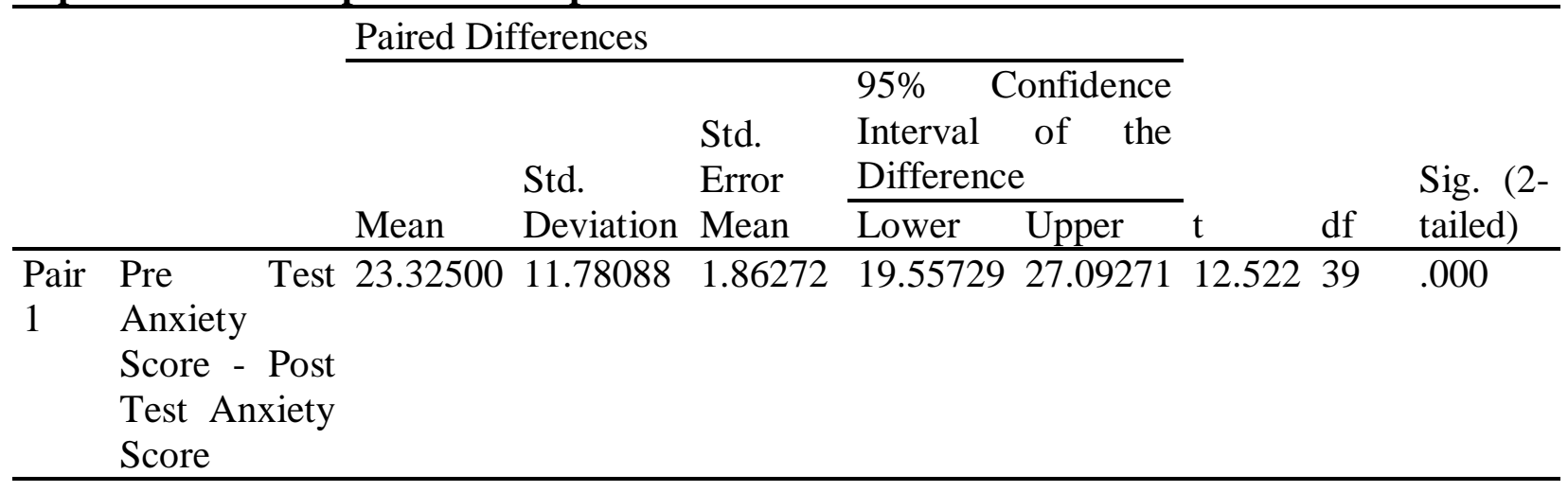

\section{Discussion}

Numerous researches have been carried out regarding the levels, types, and causes of ESL writing anxiety. But according to the researchers' best knowledge, this study is unique in its nature as it studies the effectiveness of the process-genre approach of writing for reducing the writing anxiety among ESL students at intermediate/ preuniversity level. The results have been reached through the instrument designed and tested reliably by its developer. The results found at the pretest stage demonstrated that students' on average were facing a high level of writing anxiety. This finding is consistent with the study conducted by Younis et al. (2014). Factors considered as a cause of anxiety discussed by Youbis et al. (2014) are poor teaching methodology, teacher's negative comments, time pressure, and lack of writing practice. In the present study students' interviews revealed similar themes, for example, the pressure of teacher and peer feedback and lack of appropriate teaching methodology. The study conducted by Dar \& Khan (2015) highlighted the need that teachers should 'adopt /adapt' teaching writing approaches and methods which could help reduce writing anxiety among academic writing students. Fareed, Ashraf \& Bilal (2016) in their study find out the problems and factors for poor writing skills of ESL academic leaners also maintain that writing anxiety is the issue triggered by ineffective teaching methods and lack of teaching writing practices. Gopang et al. (2018) researched to find out foreign language anxiety at Lasbela University in Pakistan, the findings of the study suggested that the majority of the students were facing high English language learning anxiety. There are several reasons, including unsuitable language teaching and the role of the langue teacher, which adds instead of reducing writing anxiety. In this present study, the role of teacher and prevalent teaching writing, mythology discussed by the participants in their interviews established the findings of the study conducted at Lasbela University.

The process - genre approach is an eclectic approach that perceives that writing is a process based on language knowledge and knowledge of the context and purpose. In this approach, Students focus on the purpose and form of writing related to a particular genre by involving the recursive progression of writing process stages e.g. prewriting, drafting, and revision. The process - genre approach was thought conducive to reduce writing anxiety due to many of its features, for example, social settings or context for a particular writing task, teachers' input, and model texts to 
understand the writing context. Furthermore, this approach helps to frame the purpose of writing, different genres of writing have different purposes and a clear understanding of the purpose is valuable to settle student writers for their writing tasks. Additional, the input giving by the students and teachers related to the purpose and form of writing is quite supportive.

"Class fellows and teacher help me in making better gives a very good feeling". (Quoted from the transcripts) This quote indicates the value of the stage 'joint construction' and continuous feedback about the writing task from both peers and teachers. In the process genre approach, the integration of process and genre based on six stages discussed in the literature is established helpful in reducing writing anxiety in this study. However, in large classes, it is quite challenging to administer this approach, but making groups within the class would be a solution.

\section{Conclusion}

In the context of ESL academic writing, anxiety is a negative factor that hampers the learning process. There is the need to understand the construct of writing anxiety in detail and find out the solution or recommendations for its alleviation. The effective teaching methodology is one of the areas to consider when talking about ESL writing anxiety. The prevalent teaching ESL writing approach in the context of Pakistan at the intermediate level is quite stereotypical in nature and studies show the results that students are facing high language anxiety in general and in academic writing in particular (Atique \& Khan 2015). This research claims that due to differences in nature and specifics the process genre approach helps reduce ESL academic writing anxiety. The process genre approach should be introduced in course design and adopted as practical writing pedagogy at intermediate/ pre-university level so that students would be able to write without anxiety at the higher education level.

\section{References}

Abate, M. D. (2019) Effect of Process-Genre Approach on Students' Writing Skill: Timuga Preparatory School 11Th Grade in Focus. Research on Humanities and Social Sciences,9(3)DOI: 10.7176/RHSS

Abdel Latif, M. M. (2015). Sources of L2 writing apprehension: A study of Egyptian university students. Journal of Research in Reading, 38(2), 194-212.

Adeel, A. (2011). A study of anxiety among the Graduation Learners of English as a Foreign Language in Pakistan. Paper presented at the 1st International Conference on Foreign Language Teaching and Applied Linguistics.

Al-Sawalha, A. M. S., \& Chow, T. V. F. (2012). The effects of writing apprehension in English on the writing process of Jordanian EFL students at Yarmouk University. International Interdisciplinary Journal of Education, 1(217), 1-15.

Atique, S. S., \& Khan, I. (2015). The Writing needs of Business Students: A Teacher's Perception in an EFL context. Journal of Education \& Social Sciences, 3(2), 231-244.

Azher, M., Anwar, M. N., \&Naz, A. (2010). An investigation of foreign language classroom anxiety and its relationship with students achievement. Journal of College Teaching \& Learning (TLC), 7(11).

Badger, R., \& White, G. (2000).A process genre approach to teaching writing.ELT Journal, 54. doi:10.1093/elt/54.2.153

Bonett, D. G., \& Wright, T. A. (2015). Cronbach's alpha reliability: Interval estimation, hypothesis testing, and sample size planning. Journal of Organizational Behavior, 36(1), 3-15.

Cheng, Y.-S. (2004). A measure of second language writing anxiety: Scale development and preliminary validation. Journal of second language writing, 13(4), 313-335.

Cheng, Y.-s.(2017). Development and preliminary validation of four brief measures of L2 language-skill-specific anxiety.System, 68, 15-25.

Cohen, L., Manion, L., \& Morrison, K. (2002).Research methods in education: Routledge.

Coleman, H., \&Capstick, T. (2012).Language in Education in Pakistan: Recommendations for Policy and Practice.Islamabad: British Council

Daly, J., \& Miller, M. (1975).The Empirical Development of an Instrument to Measure Writing Apprehension. Research in the Teaching of English, 9.

Dar, M. F., \& Khan, I. (2015).Writing anxiety among public and private sectors Pakistani undergraduate university students. Pakistan Journal of Gender Studies, 10(1), 121-136.

Davidson, P. (2019). What is Academic Writing? Edited by: WafaZoghbor, Suhair Al Alami, \&ThomaïAlexiou, 12. 
Fareed, M., Ashraf, A., \& Bilal, M. (2016). ESL learners' writing skills: Problems, factors, and suggestions. Journal of Education and Social Sciences, 4(2), 81-92.

Fareed, M., Jawed, S., \&Awan, S. (2018). Teaching English language at SSC level in private non-elite schools in Pakistan: Practices and problems. Journal of Education and Educational Development, 5(1), 80-95.

Ferris, D., \&Hedgcock, J. (2014).Teaching ESL Composition: Purpose, Process, and Practice. John S. Hedgcock. doi: $10.4324 / 9781410611505$

Getnet, A. (2019). Effects of Process- Genre Approach on Students' Argumentative Genre performance.English for Specific Purposes World, V(57), 10.

Gopang, I. B., Bughio, F. A., \&Pathan, H. (2018).Investigating foreign language learning anxiety among students learning English in a public sector university, Pakistan.MOJES: Malaysian Online Journal of Educational Sciences, 3(4), 27-37.

Hassan, B. A. (2001). The Relationship of Writing Apprehension and Self-Esteem to the Writing Quality and Quantity of EFL University Students.

Horwitz, E. K. (2010). Foreign and second language anxiety.Language Teaching, 43(2), 154-167.

Huerta, M., Goodson, P., Beigi, M., \&Chlup, D. (2017). Graduate students as academic writers: writing anxiety, selfefficacy, and emotional intelligence. Higher Education Research \& Development, 36(4), 716-729.

Hundarenko, O. (2019). Challenges of Teaching Academic Writing Skills in ESL Classroom (Based on International Teaching Experience). RevistaRomâneascăpentruEducaţieMultidimensională, 11(4), 70-83.

Huwari, I. F., \& Al-Shboul, Y. (2016).Student's strategies to reduce writing apprehension (A case study on Zarqa University).Mediterranean Journal of Social Sciences, 7(3 S1), 283.

Jennifer, J. M., \&Ponniah, R. J. (2017).Investigating the levels, types, and causes of second language writing anxiety among Indian freshmen. Journal of Asia TEFL, 14(3), 557.

Khan, H. I. (2012).English teachers' perceptions about creativity and teaching creative writing in Pakistan.American International Journal of Contemporary Research, 2(3), 57-67.

Khan, Z., \&Zaki, S. (2018) Two Instructional Frameworks for Job Application Writing: Conventional ESP-Based Strategy versus Genre-Analysis Based Strategy. Journal of Social Sciences and Interdisciplinary Research, $7(2), 110-125$.

Kim, Y., \& Kim, J. (2005). Teaching Korean university writing class. Asian EFL, 7(2), 1-15.

Liu, M., \& Ni, H. (2015). Chinese University EFL Learners' Foreign Language Writing Anxiety: Pattern, Effect, and Causes. English Language Teaching, 8(3), 46-58.

Locke, T., \&Myhill, D. (2007).Composition in the English/literacy classroom.English Teaching: Practice and Critique, 1, 1-10.

Mahboob, A. (2014). Epilogue: Understanding language variation: Implications for Pedagogy. The pedagogy of English as an international language: Perspectives from scholars, teachers, and students, 257-265.

Matsuda, P. K., \& Tardy, C. M. (2007). Voice in academic writing: The rhetorical construction of author identity in blind manuscript review. English for Specific Purposes, 26(2), 235-249.

Nguyen, C. (2019). Overview of Second and Foreign Language Writing: Characteristics, Perspectives, and Pedagogical Approaches. The Journal of Asia TEFL, 16, 1059-1068. doi:10.18823/asiatefl.2019.16.3.23.1059

Paltridge, B. (2014). Genre and second-language academic writing.Language Teaching, 47(3), 303-318.

Raimes, A. (1983). Techniques in teaching writing: ERIC.

Rankin-Brown, M. (2006).Addressing writing apprehension in adult English language learners. Paper presented at the proceedings of the CATESOL state conference.

Rizwan, M., Akhtar, S., \&Sohail, W. (2017). The frequency of local and global errors in the writing skill of undergraduate ESL learners of Pakistan. Asian Journal of Social Sciences \& Humanities Vol, 6, 1.

Sajid, M., \&Siddiqui, J. A. (2015). Lack of academic writing skills in English language at higher education level in Pakistan: causes, effects and remedies. International Journal of Language and Linguistics, 2(4), 174-186.

Singh, T. k., \&Rajalingam, S. (2012). The Relationship of Writing Apprehension Level and Self-efficacy Beliefs on Writing Proficiency Level among Pre-university Students.English Language Teaching, 5. doi: 10.5539/elt.v5n7p42

Smith, H. W. (1991). Strategies of Social Research Orlando, FL. In: Holt, Rinehart and Winston.

Tan, L., \&Zammit, K. (2016).Teaching writing and representing in the primary school years.

Topuzkanamis, E. (2015). The effect of teaching writing strategies on Turkish language teaching department freshman 
students' writing apprehension.Journal of Language and Literature Education, 13, 97-110.

Waseem, F., \&Jibeen, T. (2013). Anxiety amongst Learners of English as a Second Language: An Examination of Motivational Patterns in the Pakistani Context. International Journal of Humanities and Social Sciences (IJHSS), Vol 3.

Younas, M., Subhani, A., Arshad, S., Akram, H., Sohail, M., Hamid, M., \&Farzeen, M. (2014).Exploring the causes of writing anxiety: A case of BS English Students. Language in India, 14(8), 197-208. 